\title{
Hubungan Antara Kecerdasan Emosi dan Masa Kerja dengan Penjualan Adaptif
}

\author{
EmaYudiani \\ Fakultas Psikologi \\ Universitas Proklamasi 45 Yogyakarta
}

\begin{abstract}
Insurance agents as the marketers in the insurance business are the fiont liners for the success of the company, therefore their service qualities need to be continuously improved. One of the service qualities which needs an improvement is their adaptive selling. Adaptive selling is a selling way used by an insurance agent in such a way that he/she should adapt himself, hersell to their prospective customers needs and characteristics. The adaptive selling is important to improve since those insurance agents especially in Indonesia are still using conventional way, the same technique and the same approach to different persons. Two variables emotional intelegent and length of stay will alfect the improvement of adaptive selling to insurance agents.

This research aimed to examine the correlation between emotional int sligence and length of work with adaptive selling of life insurance agents in Palembang branch offices. This re. search employeed a purposive sampling method. The subjects of this research were 154 agents of life insurance. The data were collected by the means of two questionnaires: the adaptive selling questionnaire and the emotional intelligence quietionnaire. Data were analyned using multiple regression and product moment correlation analysis.

The result of this research are: (1) there was a very signilicant correlation between emotional intelligence with adaptive selling of life insurance agents, and (2) there was not significant correlation between length of work with adaptive selling of hife insurance agents.
\end{abstract}

Key words: adaptive selling, emotional intelligence, life insurance agents.

\section{Pendahuluan}

enghadapi era persaingan yang semakin ketat, dunia industri dituntut untuk mengupayakan seoptimal mungkin peningkatan kualitas sumber daya manusia (SDM). Kondisi di atas tidak hanya berlaku bagi industri yang menghasilkan manufactur- ing goods, akan totapi juga berlaku bagi industri yang menghasilkan jasa (service) termasuk perusahaan asuransi. Agen asuransi sebagai tenaga pemasar dalam perusahaan asuransi merupakan ujung tombak keberhasilan perusahaan, sehingga peningkatan kualitas 
SDM agen asuransi tersebut menjadi penting mengingat kegiatan asuransi d indonesia masih ketinggalan dibandingkan dengan kegiatan asuransi dalam lingkupASEAN dan dunia.

Pekerjaan sebagai agen asuransi bukan pekerjaan yang mudah. Mereka mempunyai beban psikologis yang berat karena harus bekerja sendiri dan seringkali ditekan oleh rasa penghinaan karena menghadapi berbagai macam penolakan calon nasabah. Berbagai hambatan dan tantangan dalam bekerja sebagai agen asuransi menyebabkan tingginya tingkat tum over pada posisi agen asuransi. Hal ini terlihat dari banyaknya iklan lowongan pekerjaan of media massa yang menawarkan posisi sebagai agen asuransi. Tum overyang tinggi pada pekerjaan sebagai agen asuransi ini disebabkan oleh karena mereka memandang negatif terhadap profesinya. Hal ini ditunjukkan oloh faktafakta, pertama, sulitnya mencari pekerjaan di masa sekarang mengakłbatkan pekerjaan sebagai agen asuranși dijadikan pekerjaan sementara sebelum mereka mendapatkan pekerjaan yang sesual dengan keinginan. Kedua, bekerja di perusahaan asuransi harus siap dikejar-kejar target penjualan oleh perusahaan, sehingga apabila agen asuransi tidak mampu mencapai target, mereka harus keluar dari perusahaan. Ketiga, rendahnya minat dan kesadaran masyarakat Indonesia akan pentingnya asuransi mengakibatkan agen asuransi kesulitan menjual polis asuransi.

Adanya fakta-fakta di atas, mengakibatkan agen asuransi bekerja kurang serius, sehingga kualitas pelayanannya terhadap calon nasabah tidak mengena. Menghadapi permasalahan d atas, hal penting yang harus segera ditindak lanjuti oleh perusahaan asuransi adalah meningkatkan kualitas pelayanan dan strategi penjualan agen asuransi terhadap calon pembeli polis. Upaya peningkatan kualitas kerja agen asuransi sangat berkaitan dengan kemampuan menjual polis asuransi. Salah satu kemampuan menjual yang paling tepat digunakan seorang agen dalam menjual polisasuransi adalah penjualan adaptif, yaitu penjualan yang beradaptasi dengan kebutuhan dan harapan pelanggan. Kemampuan penjualan adaptif mutlak diperlukan oleh agen asuransi dikarenakan agen asuransi tersebut akan menghadapi calon pembeli polis (prospek) yang sangat bervariasi karakteristik den kebutuhannya. Seorang agen asuransi dituntut mampu menyesuaikan diri dengan karakteristik dan kebutuhan prospek daiam hai menawarkan polis asuransi yang paling tepat.

Kenyataannya d lapangan menunjukkan bahwa kualitas SDM dan pendekatan pełayanan tenaga pomasar terhadap konsumen di Indonesia (termasuk asuransi jwa) dirasa masih roiatif kurang (Roesanto, 1996). Kondisi ini membawa konsekuensi perlunya peningkatan kemampuan menjual secara adaptif para agen asuransi dengan mempertimbangkan bahwa produk asuransi merupakan produk yang sulit dijual karena bersifat tidak nyata (intangible product), yaitu produk yang bisa dinlkmali dalam jangka waktu yang panjang. Produk seperti ini tidak bisa ditawarkan hanya dalam bentuk promosi yang bersifat massal, karena sẹtiap jenis produk asuransi spesifik bagi setiap orang (personal sellingl Oteh karena itu penyampaian irformasi tentang asuransi kepada calon nasabah harus bersifat khusus dan langsung bag setiap calon pembeli (Stanton, 1999).

Kemampuan penjualan adaptif agen asuransi tidak dapat terbentuk dengan sendirinya, tetapi ada faktor-faktor yang mempengaruhinya. Penjualan adaptif dipengaruhi oleh banyak faktor, yaitu pemantauan diri, androgini, empati, openers, pusat kendali, orientasi intrinsik, tipe kognitif, pengalaman, orientasi minat terhadap pekerjaan, dan tipe manajemen supervisor (Spiro \& Weitz, 1990; Goolsby dkk, 1992; Mclntyre dkk, 1996). Penelitian iniakan meneliti hubungan antara kemampuan penjualan adaplif dengan kecerdasan emosi sebagai salah satu karakteristik kepribadian manusia. Kecerdasan emosi diduga memberikan sumbangan dalam mempengaruhi kemampuan penjualan adaptif agen asuransi jiwa, karena mengingat kecerdasan emosi terdiri dari lima komponen 
yang sangat kompleks. Masing-masing komponen kecerdasan emosi (yaitu kesadaran diri, pengaturan diri, motivasi, empati dan keterampilan sosial) akan mempengaruhi kemampuan penjualan adaptif agen asuransi.

Penelitian ini juga akan meneliti pengalaman kerja seorang agen asuransi jwa yang diukur melalui lamanya masa kerja. Pengalaman kerja seorang agen asuransi juga mempengaruhi kemampuannya dalam melakukan penjualan adaptif. Keterampilan menjual secara adaptif akan terasah mengikuti lamanya masa kerja seorang agen asuransi jiwa.

Seorang agen asuransi dalam melaksanakan tugas, akan menggunakan kamampuankemampuan yang dimilikinya seoptimal mungkin. Kemampuan ini bisa diperoleh dari bakat, kemampuan dasar, dan pengalaman. Pengalarnan akan sangat membantu dalam mengarahkan perilaku danlangkah-langkah kerja yang diam bi jka karyawan mau belajar dari apa yang telah dialami sebelumnya. Belajar dari pengalaman akan marnpu membuat karyawan bekerja lebih baik.

Diasumsikan seorang karyawan semakin banyak pengalaman kerjanya sejalan dengan masa kerjanya. Individu dapat meningkatkan kemampuannya dalam suatu pekerjaan jika la mempunyai pengalaman. Melalui pengalarnan individu dapat belajar untuk menghadapi kesulitan-kesulitan yang muncul sehubungan dengan pekerjaannya. Belajar merupakan perubahan yang permanen dalam periaku yang dlhasilkan dari latihan atau pengalaman (Wingfield, dalam Berry \& Houston, 1993).

Berkaitan dengan penelitian ini, diasumsikan bahwa semakin lama masa kerja seorang agen asuransi akan semakin tinggi kemampuan penjualan adaptif yang diperoleh. Hal ini dikarenakan kemampuan penjualan adaptif merupakan keterampilan (skifl) yang akan terus berkembang dan terasah jika dilakukan secara terus menerus dan berulangulang. Masa kerja seorang agen asuransi yang tama akan mengasah keterampilan penjualan adaptifnya dalam berhadapan dengan para pelanggannya.
Pengalaman dalam menemui pelanggan yang sangat beragam akan memperkaya inspirasi agen asuransi dalam melakukan strategi penjualan yang adaptif terhadap pelanggan-pelanggan baru. Spiro \& Weitz (1990) mengemukakan bahwa pengalaman seorang wiraniaga akan mempangaruhi kemampuannya dalam melakukan penjualan adaptif. Semakin banyak pengalamannya dakam menggunakan berbagai macam strategi penjualan, maka wiraniaga tersebut akan semakin terampil dan luwes melakukan penjualan adaptif.

Bertitik tolak dari uraian-uraian di ałas, maka perumusan masalah dalam penelitian ini adalah untuk menelaah hubungan antara kecerdasan emosi dengan kemampuan penjualan adaptif agen asuransi jwa. Seberapa besar peran komponen-komponen kecerdasan emosi dalam mempengaruhi kemampuan penjualan adaptif agen asuransi. Penelitian ini juga untuk mengetahui apakah masa kerja agen mempengaruhi kemampuannya dalam menjual polis asuransi secara adaptif.

\section{Telaah Pustaka}

\section{Penjualan Adaptif}

Banyak definisi yang dikemukakan oieh para ahli mengenai penjualan adaptif. Masingmasing ahli memberikan batasan dan pengertiannya menurut sudut pandang mereka sendiri. Menurut Weitz \& Wright (1978) yang dimaksud penjualan adaptif adalah proses penjualan yang terdiri dari pengumpulan informasi tentang harapan-harapan para pelanggan, mengembangkan strategi penjualan berdasarkan informasi tersebut, menyalurkan signa! yang dapat dipahami untuk melaksanakan strategi, mengevaluasí pengaruh dari pesan-pesan, dan melakukan penyesuaian diri berdasarkan hasil evaluasi.

Weitz dkk (1986) mendefinisikan penjualan adaptif sebagai penyesualan perilaku menjual selama berinteraksi dengan pelanggan berdasarkan informasi yang diterima mengenai situasi penjualan. Selanjutnya dikatakan bahwa penjualan adaptif adalah 
kemampuan untuk mengadaptasi perilaku menjual secara efektif sesuai dengan tuntutan situasi penjualan. Lebih lanjut Spiro \& Weitz (1990) mengatakan bahwa seorang wiraniaga yang memiliki kemampuan penjualan adaptif tinggi akan menggunakan presentasi penjualan yang berbeda untuk setiap pelanggan dan juga mengubah perilakunya sepanjang interaksi tersebut. Begitu pula sebaliknya, tingkat penjualan adaptif yang rendah diindikasikan dengan penggunaan presentasi penjualan yang sama untuk semua pertemuan penjualan.

Reagan, dkk (1995) merangkum pengertian penjulalan adaptif dari konsep yang disusun oleh Spiro dan Weltz, yaitu pemodifikasian gaya komunikasi, format presentasi, dan isi pesan yang dilakukan oleh penjual selama berinteraksi dengan pembeli.

Berdasarkan berbagai definisi dan pengertian penjualan adaptif di atas, maka dapat disimpulkan bahwa penjualan adaptif merupakan kemampuan individu untuk beradaptasi dengan situasi penjualan berdasarkan informasi yang diterima mengenai harapan pelanggan dan adanya keyakinan akan kemampuan diri sendiri untuk melakukari perubahan-perubahan dalam presentasi. Pengertian penjualan adaptif dalam penelitian ini adalah kemampuan mengadaptasi atau mengubah perilaku menjual secara efektif saat berinteraksi dengan pembeli sesuai dengan tuntutan situasi penjualan yang meliputi bentuk pertemuan dan karakteristik pembeli yang dihadapi saat itu.

Bagi seorang wiraniaga, kemampuan untuk melakukari penjualan adaplif merupakan sesuatu hal yang vital atau sesuatu hal yang harus dimiliki. Menurut Spiro \& Weitz (1990) seseorang mampu melakukan penjualan adaptif karena dipengaruhi oleh beberapa faktor, yaitur pemantauan diri (self monitoring), androgini, empati, openers, pusat kendali (Locus or Contro'), pengalaman, orientasi minat terhadap pekerjaan, dan tipe manajemen supervisor.

Ahli lain yaitu Goolsby dkk (1992) berpendapat bahwa pemantauan diri, androgini dan orientasi intrinsik merupakan faktor-faktor yang dapat mempengaruhi individu untuk melakukan penjualan adaplif. Demikian juga dengan Mcintyre dkk (1996) yang mengemukakan bahwa pemantauan diri serta tipe kognitif seseorang mempunyai peranan dalam kemampuan penjualan adaptif. Tipe kognitif tidak secara langsung mempengaruhi kinerja wiraniaga, tetapi berpengaruh terhadap kinerja melalui penjualan adaptif.

Berdasarkan berbagai pendapat dari beberapa ahli, dapat disimpulkan bahwa penjualan adaptif dipengaruhl oleh faktor intemal (pemantauan diri, androgini, empati, openers, pusat kendali, orientasi intrinsik, tipe kognitif, pengalaman, orientasi minat terhadap pekerjaan) dan faktor eksternal (ipe manajemen supervisor). Kecerdasan emosi yang menjadi variabel dalam penelitian ini dapat dikelompokkan dalam faktor internal karena kecerdasan emosi merupakan salah satu sisi kepribadian individu (intemal).

\section{Kecerdasan Emosi}

Sebelum merrbahas tentang kecerdasan emosi, perlu dipahami terlebih dahulu makna emosi. Emosi adalah perasaan tertentu yang bergejolak (Prawitasari dkk, 1997), dan dialami seseorang serta berpengaruh terhadap kehidupan (Albin, 1994). Oleh karena itu orang tidak akan pernah dapat lepas dari emosi. Cooper \& Savaf (1998), menyebutkan bahwa emosi manusia merupakan suatu wilayah dari perasaan lubuk hati, naluri tersembunyi, dan sensasi emosi.

Menurut Goleman (1996), emosi merupakan suatu perasaan dan pikiran-pikiran khasnya, suatu keadaan biologis dan psikologis, dan serangkajan kecenderungan untuk bertindak. Kecerdasan emosi didefinisikan sebagai kemampuan untuk memotivasi diri sendiri dan bertahan menghadapi frustrasi; mengendalikan dorongan hati dan tidak melebih-lebihkan kesenangan; mengatur suasana hati dan menjaga agar beban stres tidak melumpuhkan kemampuan berpikir; berempati dan berdoa (Goleman, 1996). Pada diri individu terdapat ratusan emosi bersama dengan campuran, variasi dan nuansanya (Farhani dan Novianingtyas, 1997). Penelitian Martani (1996), 
mendapatkan bahwa emosi-emosi tertentu dapat ditentukan melalui rang sang suara atau gambar. Meskipun dalam hal ini unsur biologis memainkan peran tetapi pengalaman kehidupan serta budaya akan mempengaruhi ekspresinya. Oleh karena itu, pengelolaan emosi sangat dimungkinkan, agar kekuatan yang terkandung dalam emosi dapat dimanfaatkan secara positif.

Para pakar psikologi telah berusaha mendefinisikan kecerdasan emosi, namun masih terdapat adanya beberapa perbedaan. Goleman (1999) mengartikan kecerdasan emosi sebagai kemampuan memotivasi diri sendiri dan orang lain, kemampuan mengenall perasaan diri sendirf dan orang lain, kernampuan mengendalikan emosi, kemampuan pengaturan diri sendiri, kemampuan berempali dan kemampuan berhubungan dengan orang lain. Patton (1998) mendefíisikan kecerdasan emosi sebagai suatu kemampuan untuk menggunakan emosi secara efektif dakam mencapai suatu tujuan. Senada dengan pendapat d atas, Cooper \& Sawaf (1998), mendefinisikan kecerdasan emosi sebagai suatu kemampuan untuk mengindera, memahami dan secara efektif menerapkan kekuatan dan ketajaman emosi sebagai sumber energi, informasi, koneksi dan pengaruh yarg manusiawi.

Salovey \& Mayer (dalam Shapiro, 1997), memberikan definisi en tang kecerdasan emosi sebagai himpunan bagian dari kecerdasan emosi yang melibatkan kemampuan dalam memantau perasaan dan emosi, baik pada diri sendiri maupun pada crang lain dan kemudian menggunakan informasi ini untuk membimbing pikiran dan tindakan. Steiner (1997) memberi pengertian kecerdasan emosi sebagaj suatu kemampuan untuk mengerti emosi diri sendiri dan orang lain dan mengetahui bagaimana emosi diri sendiri terekspresikan untuk peningkatan maksimal secara etis, sebagai kekuatan pribadi.

Gardner (dalam Goleman, 1996) menyebut istilah kecerdasan emosi dengan istilah kecerdasan intrapribadi dan antarpribadi. Kecerdasan intrapribadi adalah kemampuan yang bersifat korelatif tetapi terarah ke dalam dri sendiri, yang wujudnya berupa kemampuan untuk membentuk suatu model diri sendiri yang teliti dan mengarah pada diri, suatu kemampuan untuk menggunakan model tersebut sebagai alat untuk menempuh kehidupan secara efektif. Kecerdasan antar pribadi adalah kemampuan untuk memahami orang lain, yang wujudnya berupa pemahaman terhadap apa yang memotivasi mereka, bagaimana mereka bekerja dan bagaimana mereka bekerja sama dengan sesamanya. Dalam nuarsa yang lain, ia mengatakan bahwa kecerdasan antarpribadi itu mencakup kemampuan untuk membedakan dan menanggapi dengan tepat suasana hati, temperamen, motivasi dan hasrat orang lain.

Berdasarkan uraian d atas, penelitian ini mengartikan kecerdasan emosi sebagai kemampuan seseorang dalam menggunakan atau mengelola emosi baik pada diri sendiri maupun ketika berhadapan dengan orang lain. dan menggunakannya secara efektif untuk memotivasi diri dan bertahan terhadap frustrasi dan tekanan, serta mengendalikan diri untuk mencapai hubungan yang produktif dan merah keberhasilan di tempat kerja. Kecerdasan emosi sangat bermanfaat bagi seseorang baik di tempat kerja, dalam keluarga, masyarakat maupun kehidupan spiritual, karena kecer. dasan emosi membantu seseorang memenuhl apa yang dikerjakan dan bagaimana menjaga keseimbangan antara kebutuhan pribadi dan kebutuhan orang lain.

Kecerdasan emosi sebagai suatu keseluruhan memiliki banyak komponen. Komponen-komponen yang ada terasa sangat kompleks karena terkait dengan kemampuan subjektif seseorang untuk dapat menggunakan kemampuan dan potensi emosionalnya dalam kehidupan sehari-hari. Menurut Goleman (1999), komponen kecerdasan emosi adalah kesadaran diri, pengaturan diri, motivasi, empati dan keterampilan sosial.

a Kesadaran diri yaitu mengetahui apa yang dirasakan pada suatu saat dan menggunakannya untuk memandu pengambilan keputusan bagi diri sendiri; 
memiliki tolok ukur yang realistis atas kemampuan diri dan kepercayaan diri yang kuat. Kesadaran dri memungkinkan pikiran rasional memberikan informasi penting untuk menyingkirkan suasana hati yang tidak mengenakkan. Pada saat yang bersamaan, kesadaran diri bisa membantu mengelola diri sendirl dan hubungan antar personal serta menyadari emosi dan pikir an sendiri. Patton (1998) mengatakan semakin tinggi kesadaran diri, semakin pandai dalam menangani perilaku negatif diri sendiri.

b. Pengaturan diri yaitu menangani emosi agar berdampak positif terhadap pelaksanaan tugas, peka terhadap kata hati dan sanggup menunda kenikmatan sebelum tercapai suatu tujuan dan mampu menetralisir tekanan emosi. Pengaturan diri ini mencegah kesalahan-kesalahan dan terlibat dalam masalah. Kemampuan ini bisa mengendalikan kemarahan, ketergesa-gesaan memungkinkan berfikir sebelum mengambil tindakan.

c. Motivasi diri yaitu menggunakan hasrat yang paling dalam untuk menggerakkan dan menuntun menuju sasaran, membantu mengambil inisiatif dan bertindak secara efektif dan mampu bertahan menghadapi kegagalan dan frustrasi. Kunci motivasi adalah memanfaatkan emosi, sehingga mendukung kesuksesan hidup seseorang.

d. Empati yaitu merasakan apa yang dirasakan oleh orang lain, mampu memaharni perspektif mereka, menumbuhkan hubungan saling percaya dan menyelaraskan dirt dengan orang lain. Empati memungkinkan seseorang mengetahui perasaan dan pikiran orang lain. Apabila mengembangkanempati yangdibangkitkan oleh pemahaman dan kekecewaan, perasaan dan pikiran orang lain, maka seseorang akan mampu melhat situasi dari perspektif yang lebih luas.

e. Keterampilan sosial yaitu mengendalikan emosi dengan baik ketika berhubungan dengan orang lain, cermat membaca situasi, berinteraksi dengan lancar, memahami dan bertindak bjaksana dalam hubungan antar manusia. Hasil penelitian Azis (1999) menemukan bahwa semakin tinggi kecerdasan emosi remaja, maka semakin tinggi pula kemampuan remaja menyesuakan dir dengan lingkungannnya. Kemampuan penjualan adaptif agen asuransi, bila dikaitkan dengan kecerdasan emosi, maka komponen-komponen yang terkandung di dalam kecerdasan emosi dapat digunakan untuk memprediksi keberhasilan penjualan adaptif. Komponen-komponen kecerdasan emosi, yaitu kesadaran diri, pengaturan diri, motivasi, empati dan keterampilan sosial berhubungan secara langsung dengan beberapa elemen yang menggambarkan kemampuan penjualanadaptif agen asuransi.

Komponen kesadaran dii yang merupakan komponen pertama dari kecerdasan emosi, sangal erat kaitannya dengan penjualan adaplif. Seorang agen asuransi yang mengetahui secara detail kondisi dirinya (baik kekuatan maupun keterbatasan), akan cenderung memiliki keyakinan tentang kemampuan yang dimiliki. Komponen kedua dari kecerdasan emosi yaitu pengaturan diri yang juga memiliki peranan dalam keberhasilan penjualan adaptif agen asuransi. Seorang agen asuransi yang mampu mengontrol dirinya akan dapat ber. ada tasi dengan berbagai macam situasi. Komponen motivasi jugamerupakan komponen yang penting dalam membangun kemampuan penjualan adaptif. Agen asuransi yang memilki molivasi yang kuat akan terdorong untuk berprestasi yatu dengan memenuhi standar dan target yang telah dibebankan perusahaan kepadanya. k akan tetap berjuang dengan gigith dalam mencapai tujuan, walaupun sering menghadapi penolakan-penolakan dari calon pembeli polls asuransi.

Komponen empati yang merupakan komponen keempat dari kecerdasan emosi juga berpengaruh terhadap kemampuan penjualan adaptif agen asuransi. Menurut Goleman (1999) empati adalah kesadaran seseorang terhadap perasaan, kebutuhan dan 
kepentingan orang lain. Seorang agen asuransi yang berempati terhadap pelanggannya akan berusaha mengantisipasi, mengenali dan memenuhi kebutuhan pelanggan. Komponen terakhir dari kecerdasan emosi, yaitu keterampilian sosial yang didefinisikan Goleman (1999) sebagai kepandaian seseorang daiam menggugah tanggapan yang dikehendaki pada orang lain. Keterampilan sosial ini sangat uas cakupannya dan terdii dari aspek-aspek yang kompleks, namun dalam penelitian ini hanya difokuskan pada tiga kecakapan, yaitu pengaruh dan komunikasi, manajemen konffik, serta kolaborasi dan kooperasi. Jika agen asuransi memiliki tiga kecakapan maka akan sangat membantu agen dalam melakukan presentasi penjualan polis asuransi.

\section{MasaKirja}

Menurut Myers (1983), masa kerja adalah banyaknya waktu sejak kapan seseorang terdaftar sebagai karyawan tetap sampai saal suatu penelitian dilakukan. Masa kerja erat kaitannya dengan proses penyesuaian diri. Makin lama seseorang bekerja akan semakin dapat ia menyesuaikan diri dengan pekerjaannya, semakin terampil dan terbiasa untuk melaksanakan tugas-tugasnya.

Pengertian masa kerja menurut Tim penyusun Pusat Pembinaan dan Pengembangan Bahasa Departemen Pendidikan dan Kebudayaan (1995) adalah jangka wakts seseorang sudah bekerja dalam suatu perusahaan, badan, dan sebagainya.

Berdasarkan dua pengertian di atas, maka pengertian masa kerja adalah lama waktu karyawan bekerja yang dihitung dengan bulan, dimulai pada saat seseorang terdaftar sebagai karyawan tetap dalam suatu perusahaan yang diteliti. Pertitungan masakerja clilakukan dengan menggunakan sattan butan dikarenakan untuk mendekati ketelitian semaksimal mungkin.

Pengalaman kerja terkandung d dalam masa kerja seseorang. Cascio dkk (1977) juga menyebutkan bahwa masa kerja merupakan salah satu faktor penunjang pengalaman. Pengalaman ini dipelajari seseorang selama masa kerjanya. Kemampuan individu dalam satu pekerjaan dapat meningkat jika la mempunyaj pengalaman. Melalui pengalaman bekerja, individu dapat belajar untuk menghadapi kesulitan-kesulitan yang muncul sehubungan dengan pekerjaannya. Belajar merupakan perubahan permanen dalam perilaku yang dihasilkan dari latihan atau pengalaman (Winfield, dalam Barry dan Houston, 1993).

Menurut hasil penelitian, Mulyani (1984) mengatakan bahwa pekerja yang berpengalaman menghasilkan produksi yang lebih besar daripada pekerja yang belum berpengalaman. Masa kerja yang cukup lama akan menambah kelancaran tugas para pekerja. Penelitian-penelitian ini mendukung pendapat Ghiselli dan Brown (1995) yang memperlihatkan wiraniaga asuransi baru tarpak kurang produktif dibandingkan dengan wiraniaga lama. Selain itu penelitian Asiad (1998) juga menunjukkan bahwa faktor masa kerja memberi sumbangan yang cukup besar bagi keberhasilan tugas wiraniaga asuransi (sumbangan efektif $16 \%$ ).

Hasil penelitian Schmidt, Hunter dan Outerbridge (1986) menunjukkan bahwa pengaruh terbesar dari pengalaman kerja terdapat sekitar tahun kedua dan ketiga. Hasil lain yang diperoleh adalah padajenis pekerjaan dengan tingkat kompleksitas sedang, pengalaman kerja mempunyai pengaruh besar melalui pengetahuan terhadap pekerjaannya (job knowledge).

Berdasarkan hasil-hasil penelitian d atas, dapal diketahui bahwa masa kerja merupakan variabel yang mempunyai peran bagi pelaksanaan kerja seorang karyawan. Semakin berpengalaman seorang karyawan dalam bidangnya, maka akan makin kuat pula dorongan untuk tetap menjadi anggota perusahaan. Loyalitas keryawan akan membuat karyawan tersebut berusaha seoptimal mungkin bagi kelangsungan perusahaannya. Karyawan tersebut akan terus berusaha untuk mematuhi segala peraturan yang berlaku di perusahaan tanpa merasa terpaksa. 


\section{Hipotesis}

Hipotesis penelitian ini dirumuskan sebagai berikut: (1) Ada hubungan yang positif antara kecerdasan emosi dengan kemampuan penjuaian adaptif pada agen asuransi jiwa, Semakin tinggi kecerdasan emosi, semakin tinggi kemampuan penjualan adaplif yang ditunjukkan. Sebaliknya, semakin rendah kecerdasan emosi, semakin rendah pula kemampuan penjualan adaptif yang ditunjukkan; (2) Ada hubungan yang positif antara masa kerja dengan kemampuan penjualan adaptif pada agen asuransi jiwa. Semakin lama masa kerja seorang agen asuransi, semakin tinggi kemampuan penjualan adaptif yang ditunjukkan. Sebaliknya, semakin pendek masa kerja seorang agen asuransi, semakin rendah pua kemampuan penjualar adaptif yang ditunjukkan

\section{Metode Penelitian}

Popukasi penelitian ini adalah selurth agen Asuransi Jiwa Bersama Bumiputera 1912 Cabang Palembang. Teknik pengambilan sampel dalam penelitian ini menggunakan purposive sampling yaitu pemilihan sekelompok subjek didasarkan atas ciri-ciri atau sifat tertentu yang dipandang mempunyai sangkut paut yang erat dengan ciri-ciri stau sifat-sifat populasi yang sudah diketahui sebelumnya (Hadi 1997; Sekaran, 2000). Subjekpenelitian berjumlah 154 orang yang memiliki ciri-ciri: telah masuk dalam penggolongan agen kontrak, masa kerja agen minimal 10 bulan, berjenis kelamin laki-laki dan perempuan.

Pengumpulan data data datam penelitian ini dilakukan dengan metode angket, yaitu Angket Penjualan Adaptif dan Angket Kecerdasan Emosi. Angket Penjualan Adaptif dlgunakan untuk mengetahul sejauh mana kemampuan agen asuransi dalam melakukan penjualan adaptif.Angket Kecerdasan Emosi digunakan untuk mengetahui sejaih manaagen asuransi memiliki tingkat kecerdasan emosi yang mengandung lima komponen, yaitu kesadaran emosi, pengaturan diri, empati. motivasi, dan keterampilan sosial. Data masa kerja diperoleh berdasarkan self reportsubjek penelitian daiam angket.

Analisis data yang digunakan dalam penelitian ini adalah analisis statistik. Teknik statistik yang digunakan untuk menguji hipotesis penelitian adalah anaisis regresi ganda dan analisis korelasi product moment. Perhitungan statistik dilakukan dengan komputasi melalui bantuan program Statistical Package for Social Sciences (SPSS) 9.0 for Windows.

\section{Hasil Penelitian}

\section{Uj Normalitas}

Uji normalitas sebaran dilakukan dengan menggunakan teknik Kolmogorof Smimof Goodness of Fit Test. Adapun hasil uji normalitias tersebut adalah sebagai berikut:

Tabel 1.

Hasil Uji Normalitas Sebaran

\begin{tabular}{|c|c|c|c|c|c|}
\hline Varlabel & Mean & so & $\operatorname{cs} 2$ & $\mathbf{p}$ & Ket \\
\hline 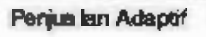 & 163.3831 & 18.0502 & 0.639 & 0,810 & Nomel \\
\hline Kecentastentemosi & 281.6688 & 28.1169 & 1245 & 0,000 & Norinel \\
\hline Masa Kerja & 68.3442 & 59.7803 & 1.026 & 0,143 & Normal \\
\hline
\end{tabular}

\section{Uj Linieritas}

1. Ji linieritas hubungan dilakukan dengan mengy Jnakan teknik analisis varians. Dalam penel tian ini, uji linieritas dilakukan sebanyak dua kali, yaitu:

Tabel 2.

Haw I U Linlortiese Hubungan

\begin{tabular}{lccc}
\hline \multicolumn{1}{c}{$\begin{array}{c}\text { Nama variabel yang } \\
\text { dikorelasikan }\end{array}$} & F & slg. & Kot. \\
\hline $\begin{array}{l}\text { Kocendasen Enosi dg Peniulan } \\
\text { Adaptif }\end{array}$ & 1.502 & 0,138 Liner \\
Masa Keja dg Ponjualan Adaptif & 1.538 & 0,132 & Linior \\
\hline
\end{tabular}

\section{Uj Hipotesis}

Pengujian hipotesis pertama yang berbunyi bahwa terdapat hubungan positif antara kecerdasan emosi dengan kemampuan 
penjualan adaptif agen asuransi jiwa. Hasil analisis regresi ganda menunjukkan harga koefisien $r$ sebesar 0,601 dengan nilai $p=$ $0,000\left(r_{\text {squara }}=0,366\right)$. Hal ini berarti hipotesis pertama teruji kebenarannya.

Pengujian hipotesis kedua yang betbuny bahwa terdapat hubungan positif antara masa kerja dengan kemampuan penjualan adaptif agen asuransi wa. Hasil analisis regresi ganda menunjukkan harga koefisien $r$ sebesar $\mathrm{nO}, 132$ dengan nilai $p=0,052\left(r_{\text {muar }}=0,017\right)$. Hal ini berati hipotesis kedua tidak terbukti atau ditolak kebenarannya. Tabel 3. d bawah ini berisi rangkuman hasil analisis regresi ganda untuk pengujian ketiga hipotesis.

Tabel3.

Rangkuman Hasi Analisłs Regresi Ganda Untuk Pengujian Hipotesis

\begin{tabular}{lccc}
\hline \multicolumn{1}{c}{ Hipotesis } & r & P & Status \\
\hline 1. KE dg PA & 0,601 & 0,000 & Sangatsignifikan \\
2 MK dg PA & 0,132 & 0,052 & Tidak signifan \\
\hline
\end{tabular}

Keterangan:

KE : Kecerdasan Emosi
FA : Penjualan Adaptif
$M K$ : Masa Kerja

\section{Analisis Data Tambahan}

Dalam peneltian in clakukan analisis data tambahan yaitu menhubungkan komponenkomponen kecerdasan emosi yang terdiri dari lima komponen, yaitu kesadaran diri, pengaturan diri, motivasi, empati dan keterampilan sosial dengan kemampuan penjualan adaptif. Teknik analisis yang digunakan adalah analisis korelasi product momentdan hasilnya adalah pada Tabel 4 sebagai berikut:

\begin{tabular}{|c|c|c|c|}
\hline Hipotesis & $\mathbf{F}$ & $\mathbf{p}$ & Status \\
\hline $\mathrm{KDdO} \mathrm{PA}$ & 0,393 & 0,000 & Samgat sigriitan \\
\hline POdg FA & 0,001 & 0,000 & Sangat signiflean \\
\hline$M \operatorname{dg} P, A$ & 0,400 & 0,000 & Saryat sigriftorn \\
\hline$E d P A$ & 0,550 & 0,000 & Sangat s'prikal \\
\hline$K S \operatorname{dg} F$ & $0,5 \$ 3$ & 0,000 & Sangatsignifkan \\
\hline
\end{tabular}

Keterangan :

KO : Kesadaran Diri
FO : Pengaturan Diri
E : Motinasi
KS : Enpati
FA : Penjualan Adaptif

Penulis juga melakukan analisis regresi ganda metode stepwise terhadap kelima komponen kecerdasan emosi, untuk mengetahui seberapa besar bobot sumbangan efektif komponen-komponen kecerdasan emosi terhadap penjualen adaplif. Berikut Tiabel 5 yang menunjukkan bobot sumbangan efektif masing-masing komponen kecerdasan emosi terhadap penjualan adaptif.

Tabel5.

Bobot Sumbangar Eloktf Komponen Kecerdasan mosi terhadap penjugtan Adaptif

\begin{tabular}{cc}
\hline Komponen & Sumbangan Efektif (SE \%) \\
\hline KD-PA & 14,9 \\
PD-PA & 35,9 \\
M-PA & 35,5 \\
E-PA & 41,1 \\
KS-PA & 40,7 \\
\hline
\end{tabular}


karyawan dalam mengadaptasi strategistrategi penjualan yang digunakan.

Kenyataan tersebut menunjukkan bahwa penjualan adaptif agen asuransi membutuhkan karakter-karakter psikologis seperti, kemampuan, bakat dan karakteristik kepribadian tertentu yang sesuai dengan tuntutan pekerjaan. Mcintyredkk (1996) menyatakan bahwaaspekaspek psikologis (termasuk karakteristik kepribadian) dapat mempengaruhi karyawan untuk mengadaptasi strategi-strategi penjualan yang digunakan. Kekurang berhasilan dalam melakukan penjualan adaptif disebabkan agen asuransi tidak memiliki karakteristik kepribadian yang optimal yang salah satunya adalah kecerdasan emosi. Bogozzi (1999) menyatakan bahwa peran emosl dalam dunia marketing tidak dapat diabaikan begitu saja, karena memberikan kontribusi yang besar dalam produktivitas tenaga pemasaran terutama pemasaran d bidang jasa.

Temuan ini didukung oleh hasil penelitian sebelumnya yang menemukan sisi internal individu sebagai prediktor timbulnya penjualan adaptif agen asuransi (wir aniaga). Penelitian Abdulah (1999) menemukan bahwa efikasi dii dapat dijadikan salah satu faktor yang mempengaruhi perijualan adaptif agen asuransi jiwa. Pada agen yang memiliki efikasi diri tinggi, akan mampu mengerahkan perhatian dan usahanya pada tuntutan situasi penjualan yang mengarah pada perilaku penjualan adaptif. Selain itu, penelitian Kristiana (1997) juga menyimpulkan bahwa pemantauan diri berhubungan secara slgnifikan dengan penjualan adaptif pada pramuniaga, Beberapa elemen yang terkandung d dalam pemantauan diri berhubungan secara langsung dengan aspek-aspek penjualan adaptif.

Seorang agen asuransi yang memiliki penjualan adaptif tinggi, la akan mampu melakukan presentasi penjualan dan pelayanan yang bervariasi dalarn menghadapi situasi penjualan yang berbeda-beda, serta mampu menyesuaikan diri selama situasisituasi tersebut. Sebaliknya, seorang agen asuransi yang memiliki tingkat penjualan adaptif rendah, ia akan menggunakan pendekatan yang sama dalam menghadapi berbaga i situasi penjualan. Sehingga keberhasilan seorang agen asuransi sangat dipengaruhi oleh kemampuannya untuk melakukan presentasi penjualan dan pelayanan terhadap pelanggan secara adaptif, dimana kemampuannya itu erat kaitannya dengan karakteristik kepribadian kecerdasan emosi yang dimilikinya.

Hasil penelitian ini menyimpulkan bahwa kecerdasan emosi mampu meningkatkan kemampuan penjualan adaptif bagi agen asuransi jwa. Kemampuan penjualan adaptif agen asuransi bila dikaitkan dengan kecerdasan emosi, maka komponenkomponen yang terkandung di dalam kecerdasan emosi dapat digunakan untuk memprediksi keberhasilan penjualan adaptif. Komponen-komponen kecerdasan emosi, yaitu kesadaran diri, pengaturan diri, motivasi, empati dan keterampilan sosial berhubungan secara langsung dengan beberapa elemen yang menggambarkan kemampuan perjualan adaplif agen asuransi.

Komponen kesadaran diri berkorelasi secara sangat signifikan dengan penjualan adaptif $(r=0,393 ; p<0,01 ;$ SE $\%=14,9 \%)$. Makin tinggi kesadaran diri seorang agen, maka makin tinggi pula penjualan adaptif yang ditunjukkan. Hasil temuan ini didukung oleh pe.relitian Abduliah (1999) yang dalam penelitiannya menyimpulkan bahwa agen asuransi yang memiliki efikasi diri (seff eficacy) tinggi akan mampu melakukan penjualan adaptif dalam penjualan asuransi. Lewicki dkk (1999) menyatakan bahwa efikasi diri merupakan salah satu aspek yang mempengaruhi kemampuan negosiasi agen asuransi dengan calon nasabahnya. Spiro \& Weitz (1990) mengatakan bahwa seorang agen asuransi yarig yakin akan kemampuan dirinya akan memudahkannya dalam menggunakan berbagai strategi penjualan yang berbeda-beda selama berinteraksi dengan pelanggan.

Komponen pengaturan diri berkorelasi secara sangaf signifikan dengan penjualan adaptif $(r=0,601 ; p<0,01 ; \mathrm{SE} \%=35,9 \%)$. 
Makin tinggi pengaturan diri seorang agen, maka makin tinggi pula penjualan adaptif yang ditunjukkan. Hasil temuan ini didukung oleh penelitian Kristiana (1997) yang menemukan bahwa pemantauan diri (self monitoring) dapat dianggap sebagal faktor penentu seorang wiraniaga untuk mampu inengadaptasi presentasi penjualan secara efektif sesual dengan situasi penjualan. Hal ini sesuai dengan peneflitian Spiro \& Weitz (1990) yang menemukan hubungan positif antara fleksibilitas interpersonal yang salah satunya adalah pemantauan diri dengan kemampuan penjulatan adaptif. Penemuan ini juga sejalan dengan pendapatGoolsbydkk (1992), yang menyatakan bahwa pemantauan diri yang dimiliki dapat mempengaruhi kinerja karyawan. Lewicki ckk (1999) menyatakan bahwa pemantauan diri mempengaruhi kemampuan negoisasi seorang wiraniaga dengan calon nasabahnya.

Komponen motivas! berkorelasi secara sangat signifikan dengan penjualan adaptif ir $=0,460 ; p<0,01 ;$ SE $\%=35,5 \%$ ). Makin tinggi motivasi seorang agen, maka makin tinggi pula penjualan adaptif yang ditunjukkan. Temuan ini sejalan dengan pendapat Goleman (1996) yang mengatakan bahwa motivasi merupakan faktor penting yang berperanan dalam menentukan keberhasilan kerja seseorang yang dalam penelitian ini adalah melakukan penjualan adaptif. Orang yang bekerja dengan motivasi tinggi, akan berusaha secara maksimal guna mendapatkan hasil kerja yang baik, dan selalu akan berusaha mengembangkan dirinya, selelu merasa senang serta mendapatkan kepuasan dalam pekerjaannya (Doelhadi, 2001).

Komponen empati berkorelasi secara sangat signifikan dengan penjualan adaptif ( $r$ $=0,550 ; p<0,01 ;$ SE \% $=41,1 \%)$. Makin tinggi empati seorang agen, maka makin tinggi pula penjualan adaptif yang ditunjukkan. Hasil temuan ini mendukung pernyataan Spiro \& Weitz (1990) yang mengatakan bahwa empati sangat diperlukan dalam melakukan penjualan secara adaptif, agar harapan dari setlap pelanggan dapat dipenuhi oleh seorang agen asuransi. Merurut Goleman (1999) empati adalah kesadaran seseorang terhadap perasaan, kebutuhan dan kepentingan orang lain. Seorang agen asuransi yang berempati terhadap pelanggannya akan berusaha mengantisipasi, mengenali dan memenuhi kebutuhan pelanggan. Usaha-usaha ini sangat berkaitan dengan penjualan adaptif yang didalamya terkandung bagaimana seorang agen berusaha menyesuaikan diri dengan situasi penjualan yang dihadapi (penjualan adaplif).

Komponen keterampilan sosial berkorelasi secara sangat signifikan dengan penjualan adaptif $(r=0,513 ; p<0,01 ;$ SE $\%=40,7$ \%).Makin tinggi keterampilan sosial seorang agen, maka makin tinggi pula penjualan adaptif yang ditunjukkan. Temuan ini sejalan dengan pendapat Stanton (1999) yang menyatakan bahwa pekerjaan sebagai tenaga penjual sangat dibutuhkan kemampuan sosialisasi dengan pelanggan, sehingga dibutuhkan kecerdasan sosial yang tinggi terutama menghadapi pelanggan yang sulit. Goleman (1999) menemukan bahwaorang yang merrilki kecakapan-kecakapan sosial seperti kemampuan mempengaruhi, komunikasi, manajemen konflik, serta kolaborasi dan kooperasi akan menujang keberhasilannya dalam dunia kerja. Pendapat ini bila dikaitkan dengan hasil penelitian akan sangat relevan, karena seorang agen yang memiliki kecakapan-kecakapan sosial di atas akan dengan mudah melakukan penjualan adaptif.

Hipotesis kedua yang menyebutkan bahwaada hubungan antara masa kerja ctengan kemampuar perjualan adaptif pada agen asuransi jwa tidak terbukti. Temuan ini tidak mendukung pendapat Levy dan Sharma (1994) yang mengatakan bahwa pengalaman kerja akan meningkatkan kemampuan penjualan adaptif seorang wiraniaga dan Spiro \& Weitz (1990) yang mengemukakan bahwa pengalaman seorang wiranlaga akan mempengaruhi kemampuannya dalam melakukan penjualan adaptif. Hasil penelitian ini menunjukkan bahwa tidak selalu individu yang masa kerjanya lebih lama akan lebih baik penjualan adaptifnya. Penelitian yang mencoba mengetahui seberapa besar 
kemampuan prediktif masa kerja terhadap keberhasilan kerja belum menunjukkan hasil yang konsisten (Schmidt dkk, 1986). Berry dan Houston (1993) menyatakan bahwa meskipun beberapa bukti menunjukkan kemampuan prediktif masa kerja untuk meramalkan keberhasilan di masa mendatang, hal ini harus dilakukan dengan hati-hati disebabkan faktor individual dan faktor-faktor lain dapat mempengaruhi hubungan antara masa keja dengan penjualan adaptif.

Agen asuransi yang mempunyai masa kerja lebih lama tidak berarti kemampuan penjualan adaptifnya iebih bak daripada agen yang baru (dalam penelitian ini rata-rata 64 bulan atau sekitar 5 tahun). Ada beberapa kemungkinan penyebab dari kenyataan ini, pertama, kemungkinan mereka mengaiami kejenuhan dalam melakukan pekerjaannya sehingga mereka kurang termotivasi untuk bekerja sekeras-kerasnya mengejar target yang seliap bulannya hans dipenuhi. Berbeda dengan agen baru yang mungkin semangat dan kesungguhan yang dimiliki dalam beiajar mengembangkan keterampilan menjual lebih tinggi dibanding para seniomya. Kedua, min at terhadap pekerjaan menurun seiring dengan lamanya bokerja. Mereka merasa sudah cukup puas dengan kemampuan menjual yang dimiliki, sehingga kemampuan penjualan adaptif-nya tidak berkembang.

Kesimpulan yang dapat diambil berdasarkan hasil penelitian pada agen $A \sqrt{ } B$ Bumiputera 1912 Cabang Palembang adalah: (1) Ada hubungan antara kecerdasan emosi dengan kemampuan penjualan adaptif pada agen asuransi jwa. Makin tinggi kecerdasan emosi, makin tinggi pula kemampuan penjualan adaptif yang ditunjukkan. Kontribusi kecerdasan emosi terhadap penjualan adaptif diketahui sebesar $0,366(36,6 \%)$, yang menunjukkan bahwa kecerdasan emosi memberikan sumbangan efektif sebesar 36,6 $\%$ terhadap penjualan adaptif; (2) Tidak ada hubungan antara masa kerja dengan kemampuan penjualan adaptif pada agen asuransi jwa. . Kontribusi masa kerja temadap penjualan adaptifdiketahui sebesar $0,017(0,17$ \%), yang menunjukkan bahwa masa kerja memberikan sumbangan efektif sebesar 0, 17\% terhadap penjualan adaptif; (3) Berdasarkan hasil perhitungan analisis korelasi product moment, diperoleh temuan bahwa kelima komponen kecerdasan emosi, yaitu kesadaran diri, pengaturan diri, motivasi, empatl dan keterampilan sosial berhubungan secara sangal signifikan dengan penjualan adaptif; (4) Berdasarkan hasi pertitungan analisis regresi ganda metode stepwise, ditemukan bahwa dari kelima komponen kecerdasan emosi tersebut bahwa komponen kesadaran diri memberikan sumbangan efektif sebesar $14,9 \%$, komponen pengaturan diri $35,9 \%$, komponen motivasi $35,5 \%$, komponen empati $41,1 \%$, dan komponen keterampilan sosial $40,7 \%$. Komponen keterampilan social memberikan sumbangan efektif yang paling dominan dibandingkan komponen-komponen lainnya; (5) Berdasarkan hasil perhitungan kategorisasi diperoleh temuan bahwa tingkat kecerdasan emosi dan penjualan adaptif agen asuransi berada pada taraf sedang yang cenderung tinggi. Hal ini dapat menyimpulkan bahwa kecerdasan emosi yang dimiliki agen asuransi akan mempengaruhi penjualan adaptif dan keadaan ini akan ikut menentukan keberhasilar, agen tersebut.

Saran-saran yang dapat direkomendasıcan berdasarkan hasil penelitian ini adalah: Bagi perusahaan, kecerdasan emosi dapat digunakan sebagai salah satu bahan pertimbangan dalam proses seleksi agen baru. Tujuannya agar perusahaan dapat merekrut agen dengan kecerdasan emosi yang tinggi. sehingga diharapkan dapat membantu meningkatkan kemampuan penjualan adaptif agen yang pada akhirnya mengarah pada peningkatan penjualan polis asuransi. Bagi individu yang telah menjadi agen asuransi, peningkatan penjualan adaptif agen dapat dilakukan dengan mengadakan pelatihan tentang komponen-komponen yang terkandung dalam kecerdasan emosi, terutama komponen keterampilan social yang memberikan kontribusi terbesar dalam mempengaruhi 
penjualan adaptif. Hasil penelitian ini juga merekomendasikan penggunaan konsep kecerdasan emosi dalam evaluasi kinerja, terutama menyangkut perkembangan tingkat penjualan adaplif agen asuransi jiwa. Berkaitan dengan masa kerja, hasil penelitian ini menyarankan tidak perlu mempertimbangkan faktor lamanya masa kerja dalam evaluasi kinerja penjualan adaptif agen asuransi jwa. Agen asuransi yang masa kerjanya belum lama tetap dapat menunjukan tingkat penjualan adaptif yang tinggi. Pengalaman kerja di bidang pemasaran juga tidak dapat dijadikan indikator dalam proses seleksi agen baru.

Bagi peneliti selanjutnya perlu memperhatikan variabel-variabel lain yang dapat mempengaruhi penjualan adaplif, misalnya yaitu pemantauan diri (self monitoring). androgini, empati, openers, pusat kendali (tocus of control), orientasi intrinsik, tipe kognitif, orientasi minat terhadap pekerjaan dan tipe manajemen supervisor. Hal ini dikarenakan variable-variabel d luar kecerdasan emosi hi memberikan sumbangan efektif sebesar 63,4 \% bagi penjualan adaptif. Mengingat kecerdasan emosi merupakan konsep yang mash sangat luas, untuk penelitian selaniutnya sebaiknya diperhatikan faktor-faktor yang mempengaruhi kecerdasan emosi itu sendiri, sehingga didapatkan hasil yang lebih komprehensif. Konsep penjualan adaptif juga pertu diperjelas aspek-aspek yang membentuknya, sehingga tidak terjadi overtap di antara masingmasing aspek tersebut.

\section{Daftar Pustaka}

Abdullah, S.M. (1999). Hubungan Efikasi Diri dengan Adaptive Selling pada Agen Asuransi Jiwa. Skripsi. (tidak diterbitkan). Yogyakarta: Fakultas Psikologi UGM.

Albin, R.S. (1994). Emosi: Bagaimana Mengenali, Menerima dan Mengarahkannya. Yogyakarta: Kanisius.

Asíad, M. (1998). Psikologi Industri. Yogyakarta: Penerbit Liberty.

Azis. (1999). Hubungan antara Kecerdasan Emosi den PenyesuaianDiridan Kecenderungan Berperilaktu Delinkuen padaRemaja. Tesis. (tidak diterbitkan). Yogyakarta: Progam PascaSarjana UGM.

Berry. LM., \& Houston, J.D. (1993). Psychology at Work. Boulevard Dubuque: WCB Brown \& Benchmark Publishing.

Bogozzi, R.M., Gopinatth and P Nyer. (1999). The Roleof Emotions in Marketingi. Journal of Business Research, 31, 39-47.

Cascio, W.F., \& Enzo, RV. (1977). Behavioral of Raters. Joumal of Applied Psychology, 62, 3.

Cooper, A. K., \& Sawaf, A. (1998). EXECUTNE EQ : Kocordasan Emosional dalam Kepemimpinan dan Organisasi. Alex Tri K.W. (pen.). Jakarta: Grameda.

Doelhadi, A.S. (2001). Kerja dalam Dimensi tinjauan Psikologi. Media Psikologi Insan. Vol. 3. No. 1, 27-40, Mei 2001. Surabaya: Fakultas Psikologi Universitas Airlangga.

Farhani, I., \& Novianingtyas, I. (1997). Mempersiapkan EQ Semenjak Dini untuk Keberhasilan Berkarir of Dunia Kerja. Makalah Konggres VII ISPSI 
(tidak diterbitkan). Yogyakarta.

Ghiselli, E.E., \& Brown, C.W. (1995). Personnel industrial Psychology. New York Mc Graw Hill Book Company inc.

Goleman, D. (1996). Kacerdasan Emosional. Hermaya, T. (penerjemah). Jakarta: Grameda.

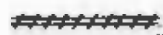
(1999). KecerdasanEmasi uniuk Mencapai Puncak Prestasi. Widodo A.TK. (penerjemah). Jakarta: Gramedia.

Goolsby, J.R., Lagace, R.R, \& Booromis. (1992). Psychological Adaptiveness and Sales Performance. Joumai of Personal Selling and Sales Management, 12 (2), 5266 .

Kristiana, Retno. (1997). Hubungan antara Pemantauan Diri dengan Adaplive Selling pada Pramuniaga Galeria Matahari Yogyakarta. Skripsi. (tidak diterbitkan). Yogyakarta: Fakultas Psikologi UGM.

Levy, \& Sharma, A. (1994). iAdaptive Selling: The Role of Gender, Age, Sales Experence and Educationi. Journal of Business Research, 31, 39-47.

Lewicki, R.J., Saunders, D.M.1 \& Minton, J.W. (1999). Negotiation.NewYork: McGraw Hill Book Company Inc.

Martani. (1996). Mengenalf Emosi Melalui Rangsang Gambardan Suara. Laporan Penelitian. (tidak diterbitkan). Yogyakarta: Fakultas Psikologi UGM.

Mclntyre, R.P., Wheatley, EW., \& Uhr, E.B. (1996). Psychological Influences on Adaplive Selling Techniques in The Real Estate Sales Force. Joumal of Professiona/Service Marketing 13(2), 137-150.

Mulyani, S. (1984). Pengaruh Kecerdasan,
Ketelitian, Kecepatan dan Masa Kerja Terhadap Produktivitas Kerja Karyawan bagian Ring Spinningpada PbrikTekstil Damatex di Tangerang. Skripsi. (tidak diterbitkan). Yogyakarta: Fakultas Psikologi UGM.

Myers. (1983), Social Psychology. Tokyo: Mc Graw Hill Book Company Inc.

Patton, P. (1998). EQ(KiscendasanEmosional) di Tempat Kerja. Zaini Dahlan (penerjemah). Julia Tahitoe (ed.). Jakarta: Delaprasta.

Prawitasari, J.E.., Martani, W. \& Adiyanti, M.G. (1997). Konsep Emosi Orang Indonesia: Pengungkapan dan Pengertian Emosi melalui Komunikasi Nonverbal di Mesyarakat yang Berbeda Latar Belakang Budaya. Laporan Penelitian. (tidak diterbitkan). Yogyakarta: Fakultas Psikologi UGM.

Reagan, C.C., Capella, L.M., \& Miles, M.P. (1995). Adaptive Selling to the Professional Service Market: Utilizing The Myers-Briggs Type Indicator to Direct Style Flexing. Journal of Professionat Service Marketing, 11 (2), 23-43.

Rousanto. (1996). Warta Bumiputera. No. 26, November-Desember, Jakarta.

Schmidt, F.L., Hunter, J.E.E., \& Outerbridge. A.N. (1986). Impact of Job Experience and Ability on Job Knowedge, Work Sample Performance, and Supervisory Rating of Job. Performance. Joumal of Appliad Psychology. 71, 432.439.

Shapiro, L.E. (1997). Mengajarkan Emotional Intelligence Pada Anak. Alek Tri K.W. (pen.). Jakarta: Gramedia.

Spiro, R.L., \& Weitz, B.A. (1990). IAdaptive Selling: Conceptualization, Measurement and Nomological Validityí. Jour- 
nal of Maketing Research, 28 (February), 61-69.

Stanton, W (1999). Management of Sales Fonce Singapore: Mc Graw Hill Book Company lnc.

Steiner, C. (1997). Achisving Emotional Literacy: A Personal Program to increase Your Emotional Intelligence. New York: Advance Book.

Tim Penyusun Pusat Pembinaan dan Pengembangan Baahasa, Departemen Pendidikan dan Kebudayaan. (1995).
Kamus Besar Bahasa Indonesia. Jakarta: Balai Pustaka.

Weitz, B.A., Sujan, $H_{\text {, }}$ \& Sujan, M (1986). iKnowledge, Motivation, and Adaptive Behavior: A Framework for Improving Selling Effectivenessî. Joumal of Mar. keting, 50 (October), 174-19t.

Waitz, B.A, \& Wright, P. (1978). iThe Relationship Between Selesperson Performance and Understanding of Customer Decision Makingî. Joumal of Marketing Research, 15 (November), 501-516. 